\title{
Genome sequences published outside of Standards in Genomic Sciences, July - October 2012
}

\author{
Oranmiyan W. Nelson ${ }^{1}$ and George M. Garrity ${ }^{1}$ \\ ${ }^{1}$ Editorial Office, Standards in Genomic Sciences and Department of Microbiology, \\ Michigan State University, East Lansing, MI, USA
}

The purpose of this table is to provide the community with a citable record of publications of
ongoing genome sequencing projects that have led to a publication in the scientific literature.
While our goal is to make the list complete, there is no guarantee that we may have omitted
one or more publications appearing in this time frame. Readers and authors who wish to
have publications added to subsequent versions of this list are invited to provide the biblio-
graphic data for such references to the SIGS editorial office.

\section{Domain Archaea}

Phylum Crenarchaeota

"Thermogladius cellulolyticus" 1633, sequence accession CP003531 [1]

\section{Phylum Euryarchaeota}

Methanomassiliicoccus luminyensis, sequence accession CAJE01000001 through

CAJE01000026 [2]

Pyrococcus sp. Strain ST04, sequence accession CP003534 [3]

\section{Domain Bacteria}

Phylum Nitrospirae

Leptospirillum ferrooxidans Strain C2-3, sequence accession AP012342 [4]

\section{Phylum Cyanobacteria}

Prochlorococcus marinus MED4, sequence accession BX548174 [5]

\section{Phylum Proteobacteria}

Acinetobacter sp. Strain HA, sequence accession AJXD00000000 [6]

Acinetobacter venetianus RAG-1' ${ }^{\mathrm{T}}$, sequence accession AKIQ00000000 [7]

Agrobacterium tumefaciens CCNWGS0286, sequence accession AGSM00000000 [8]
Alcaligenes faecalis subsp. faecalis NCIB 8687, sequence accession AKMR01000001 through AKMR01000186 [9]

Alishewanella agri $\mathrm{BL} 06^{\mathrm{T}}$, sequence accession AKKU00000000 [10]

Alishewanella aestuarii Strain B11 ${ }^{\mathrm{T}}$, sequence accession ALAB00000000 [11]

Bacillus methanolicus MGA3, sequence accession ADWW00000000 [12]

Bacillus methanolicus PB1, sequence accession AFEU00000000 [12]

"Candidatus Sulfurovum sediminum", sequence accession AJLE00000000 [13]

Bartonella birtlesii strain IBS $135^{\mathrm{T}}$, sequence accession AKIP00000000 [14]

Brucella abortus A13334, sequence accession CP003176.1 (Chromosome I),CP003177.1

(Chromosome II) [15]

Brucella canis Strain HSK A52141, sequence accession CP003174.1 (chromosome I), and CP003175.1 (chromosome II) [16]

Brucella melitensis S66, sequence accession AHWB00000000 [17]

Brucella melitensis16M, sequence accession AHWC00000000 [18]

Brucella melitensis 16M1w, sequence accession AHWD00000000 [18]

Brucella melitensis 16M13w, sequence accession AHWE00000000 [18]

Burkholderia sp. Strain KJ006, sequence accession CP003514 (chromosome I), CP003515 
(chromosome II), CP003516 (chromosome III), and CP003517 (plasmid pKJ006) [19].

Burkholderia terrae Strain BS001, sequence accession AKAU00000000 [20]

Burkholderia thailandensis MSMB43, sequence accession AJXB00000000 [21]

Catenovulum agarivorans $\mathrm{YM}^{\mathrm{M}}{ }^{\mathrm{T}}$, sequence accession AJWM00000000 [22]

Citrobacter sp. Strain A1, sequence accession AKTT00000000 [23]

Cronobacter sakazakii ES15, sequence accession CP003312 [24]

Dickeya zeae Strain ZJU1202, sequence accession AJVN00000000 [25]

Enterobacter cloacae GS1, sequence accession AJXP00000000 [26]

Enterococcus faecium Clinical Isolate LCTEF128, sequence accession AJUP00000000 [27]

Enterobacter radicincitans DSM16656 ${ }^{\mathrm{T}}$, sequence accession AKYD00000000 [28]

Escherichia coli J53, sequnce accession AICK00000000 [29]

Escherichia coli LCT-EC106, sequence accession [30]

Escherichia coli NCCP15647, sequence accession AJMB00000000 [31]

Escherichia coli W26, sequence accession AGIA00000000 [32]

Gluconobacter oxydans WSH-003, sequence accession AHKI00000000 [33]

Halomonas stevensii S18214 ${ }^{\mathrm{T}}$, sequence accession AJTS00000000 [34]

Helicobacter cinaedi Strain PAGU611, sequence accession AP012344 (chromosome) and AP012345 (plasmid) [35]

Helicobacter pylori hpEurope Strain N6, sequence accession CAHX01000001 to CAHX01000054 [36]

Herbaspirillum lusitanum P6-12, sequence accession AJHH00000000 [37]

Herbaspirillum sp. Strain GW103, sequence accession AJVC00000000 [38]

Hydrocarboniphaga effusa strain AP103', sequence accession AKGD00000000 [39]

Hydrogenophaga sp. Strain PBC, sequence accession AJWL00000000 [40]
Klebsiella oxytoca E718, sequence accession CP003683 [41]

Methylobacterium extorquens sp. strain 4-46, sequence accessions NC_010511, NC_010373, NC_010374 [42]

Methylobacterium extorquens strain BJ001, sequence accessions NC_010725, NC_010727, NC_010721 [42]

Methylobacterium extorquens strain CM4, sequence accessions NC_011757, NC_011758, NC_011760 [42]

Methylobacterium extorquens strain JCM 2831, sequence accessions NC_010510, NC_010509, NC_010514, NC_010517, NC_010518, NC_010502, NC_010504, NC_010507 [42]

Methylobacterium extorquens strain ORS 2060, sequence accessions NC_011894,NC_011892, NC_011887, NC_011893, NC_011895, NC_011888, NC_011889, NC_011890 [42] Methylobacterium extorquens strain PA1, sequence accessions NC_010172 [42]

Methylobacterium sp. Strain GXF4, sequence accession AKFK00000000 [43]

Methylophaga sp. Strain JAM1, sequence accession CP003390 [44]

Methylophaga sp. Strain JAM7 sequence accession CP003380 (chromosome), CP003381 (plasmid) [44]

Modestobacter marinus Strain BC501, sequence accession F0203431 [45]

Mycobacterium massiliense M18, sequence accession AJSC00000000 [46]

Neisseria meningitidis Capsule Null Locus Strain, sequence accession CAJS01000001 through CAJS01000042 [47]

Novosphingobium sp. Strain $\operatorname{Rr} 2-17$, sequence accession AKFJ00000000 [48]

Providencia stuartii Clinical Isolate MRSN 2154, sequence accession CP003488 [49] Pseudaminobacter salicylatoxidans KCT001, sequence accession CAIU00000000 [50] Pseudomonas aeruginosa Strain SJTD-1, sequence accession AKCM00000000 [51] Pseudomonas aeruginosa Strain XMG, sequence accession AJXX00000000 [52]

Pseudomonas fuscovaginae CB98818, sequence accession ALAQ00000000 [53]

Pseudoalteromonas issachenkonii PAMC 22718, sequence accession AJTK00000000 [54] 
Pseudomonas sp. Strain HYS, sequence accession AJJP00000000 [55]

Pseudomonas pseudoalcaligenes KF707, sequence accession AJMR00000000 [56]

Pseudomonas putida Strain ND6, sequence accession CP003588 [57]

Pseudomonas putida Strain SJTE-1, sequence accession AKCL00000000 [58]

Pseudomonas sp. Strain M47T1, sequence accession AJWX00000000 [59]

Pseudomonas stutzeri TS44, sequence accession AJXE00000000 [60]

Ralstonia sp. strain PBA, sequence accession AJWL00000000 [61]

Rhodanobacter strain DSM 23569, sequence accession AGIL00000000 [62]

Rhodanobacter strain 115 , sequence accession AJXS00000000 [62]

Rhodanobacter DSM 17631, sequence accession AJXT00000000 [62]

Rhodanobacter DSM 18449, sequence accession AJXU00000000 [62]

Rhodanobacter DSM 18863, sequence accession AJXW00000000 [62]

Rhodanobacter DSM 24678, sequence accession AJXV00000000 [62]

Rickettsia conorii subsp. caspia, sequence accession AJUR00000000 [63]

Rickettsia australis strain Phillips ${ }^{\mathrm{T}}$, sequence accession AKVZ00000000 [64]

Rickettsia sp. Strain MEAM1, sequence accession AJWD00000000 [65]

Rickettsia conorii subsp. israelensis, sequence accession AJVP00000000 [66]

Serratia plymuthica Strain PRI-2C, sequence accession AJTB00000000 [67]

Serratia marcescens strain LCT-SM213, seqeunce accession AJUV00000000 [68]

Sinorhizobium fredii USDA257, sequence accession CP003563 through CP003582 [69]

Sphingobium indicum B90A, sequence accession AJXQ00000000 [70]

Stenotrophomonas maltophilia PML168, sequence accession CAJH01000001 through CAJH01000097 [71]

Salmonella enterica serotype Newport CVM35185, sequence accession AHTJ00000000 [72]
Salmonella enterica serotype Newport

CVM33953, sequence accession

AHTM00000000 [72]

Salmonella enterica serotype Newport

CVM21550, sequence accession

AHTT00000000 [72]

Salmonella enterica serotype Newport

CVM21538, sequence accession

AHTV00000000 [72]

Salmonella enterica serotype Newport

CVM37978, sequence accession

AHUC00000000 [72]

Salmonella enterica serotype Newport

CVM19593, sequence accession

AHUD00000000 [72]

Salmonella enterica serotype Newport

CVM19443, sequence accession

AHUB00000000 [72]

Salmonella enterica serotype Newport

CVM19470, sequence accession

AHUE00000000 [72]

Salmonella enterica serovar Typhi UJ308A, sequence accession AJTD00000000 [73]

Salmonella enterica Serovar Typhi UJ816A, sequence accession AJTE00000000 [73]

Serratia sp. Strain M24T3, sequence accession [74]

Sulfuricella denitrificans skB26, sequence accession BAFJ01000001 through

BAFJ01000023 [75]

Xanthomonas campestris JX, sequence accession AJV000000000 [76]

Yersinia pestis Strain 2501, sequence accession AKVQ00000000 [77]

\section{Phylum Firmicutes}

Aeromonas aquariorum, sequence accession BAFL01000001 through BAFL01000036, and AP012343 [78]

Aerococcus viridans LL1, sequence accession AJTG00000000 [79]

Bacillus anthracis H9401, sequence accession CP002091.1 ( chromosome), CP002092.1.1 (plasmid pX01), and CP002093.1 (plasmid pX02) [80]

Bacillus atrophaeus C89, sequence accession AJRJ00000000 [81]

Bacillus cereus NC7401, sequence accession AP007209 (chromosome), AP007210 (plasmid 
pNCcld), AP007211 (plasmid pNC1, $48 \mathrm{~kb}$ ), AP007212 (plasmid pNC2, 5 kb), AP007213 (plasmid pNC3, $4 \mathrm{~kb}$ ), and AP007214 (plasmid pNC4, $3 \mathrm{~kb}$ ) [82]

Bacillus siamensis KCTC $13613^{\mathrm{T}}$, sequence accession AJVF00000000 [83]

Bacillus sp. Strain 5B6, sequence accession AJST00000000 [84]

Bacillus sp. Strain 916, sequence accession AFSU00000000 [85]

Citreicella aestuarii Strain 357, sequence accession AJKJ00000000 [86]

Clostridium beijerinckii Strain G117, sequence acceession AKWA00000000 [87]

Corynebacterium pseudotuberculosis Strain 1/06-A, sequence accession CP003082 [88] Enterobacter sp. Isolate Ag1, sequence accession AKXM00000000 [89]

Enterococcus faecalis D32, sequence accession CP003726 through CP003728 [90]

Enterococcus faecalis strain NP-10011, sequence accession AB712291 [91]

Enterococcus hirae (Streptococcus faecalis) ATCC 9790, sequence accession CP003504 (chromosome), NC_015845 (plasmid pTG9790) [92]

"Geobacillus thermoglucosidans" TNO-09.020, sequence accession AJJN00000000 [93]

Lactococcus garvieae IPLA 31405, sequence accession AKF000000000 [94]

Lactobacillus mucosae LM1, sequence accession AHIT00000000 [95]

Lactobacillus rossiae DSM 15814, sequence accession AKZK00000000 [96]

Paenibacillus polymyxa OSY-DF, sequence accession AIPP00000000 [97]

Pediococcus pentosaceus strain IE-3, sequence accession CAHU01000001 through CAHU01000091 [98]

Pelosinus fermentans A11, sequence accession AKVM00000000 [99]

Pelosinus fermentans B4, sequence accession AKVJ00000000 [99]

Pelosinus fermentans JBW45, sequence accession AKV000000000 [100]

Pelosinus fermentans R7, sequence accession AKVN00000000 [101]
Planococcus antarcticus DSM 14505, sequence accession AJYB00000000 [102]

Pseudomonas stutzeri Strain JM300, sequence accession CP003725 [103]

Rhodococcus sp. strain DK17, sequence accession AJLQ00000000 [104]

Staphylococcus aureus Strain LCT-SA112, sequence accession AJLP00000000 [105]

Staphylococcus capitis QN1, sequence accession AJTG00000000 [106]

Staphylococcus equorum subsp. equorum Mu2, sequence accession CAJL01000001 to CAJL01000030 [107]

Staphylococcus hominis ZBW5, sequence accession AKGC00000000 [108]

Staphylococcus saprophyticus subsp.

saprophyticus M1-1, sequence accession AHKB00000000 [109]

Streptococcus mutans GS-5, sequence accession CP003686 [110]

Streptococcus pyogenes M1 476, sequence accession AP012491 [111]

Streptococcus salivarius PS4, sequence accession AJFW00000000 [112]

Streptococcus thermophilus Strain MN-ZLW002, sequence accession CP003499 [113]

Ureibacillus thermosphaericus Strain ThermoBF, sequence accession AJIK00000000 [114]

\section{Phylum Tenericutes}

Mycoplasma leachii Strain PG50T, sequence accession CP002108.1 [115]

Mycoplasma mycoides subsp. mycoides, sequence accession CP002107.1 [115]

Mycoplasma wenyonii Strain Massachusetts, sequence accession CP003703 [116]

\section{Phylum Actinobacteria}

Actinomyces massiliensis Strain $4401292^{\mathrm{T}}$, sequence accession AKIO00000000 [117]

Bifidobacterium animalis subsp. lactis B420, sequence accesion CP003497 [118]

Bifidobacterium animalis subsp. lactis Bi-07, sequence accesion CP003498 [118]

Bifidobacterium bifidum strain BGN4, sequence accession CP001361 [119]

Brevibacterium massiliense Strain $541308^{\mathrm{T}}$, sequence accession CAJD00000000 [120] 
Corynebacterium bovis DSM 20582, sequence accession AENJ00000000 [121]

Corynebacterium diphtheriae Biovar Intermedius NCTC 5011, sequence accession AJVH00000000 [122]

Corynebacterium pseudotuberculosis strain 1/06-A, sequence accession CP003082 [123] Corynebacterium pseudotuberculosis strain 3/99-5 sequence accession CP003152.1 [124] Corynebacterium pseudotuberculosis strain 42/02-A, sequence accession CP003062 [124] Microbacterium yannicii, sequence accession CAJF01000001 through CAJF01000067 [125]

Micromonospora lupini Lupac 08, sequence accession CAIE01000001 [126]

Mycobacterium bolletii Strain M24, sequence accession AJLY00000000 [127]

Mycobacterium intracellulare Clinical Strain MOTT-36Y, sequence accession CP003491 [128]

Mycobacterium massiliense M18, sequence accession AJSC00000000 [129]

Mycobacterium massiliense strain GO 06, sequence accession CP003699 [130]

Mycobacterium massiliense strain M154, sequence accession AJMA00000000 [131]

Mycobacterium tuberculosis RGTB327, sequence accession CP003233 [132]

Mycobacterium tuberculosis MTB423, sequence accession CP003234 [132]

Parascardovia denticolens IPLA 20019, sequence accession AKII00000000 [133]

Saccharothrix espanaensis DSM 44229T, sequence accession HE804045 [134]

Streptomyces auratus Strain AGR0001, sequence accession AJGV00000000 [135]

"Streptomyces cattleya" DSM46488', sequence accession FQ859185 and FQ859184 [136]

Streptomyces globisporus C-1027, sequence accession AJU000000000 [137]

Streptococcus mutans GS-5, sequence accession CP003686 [138]

Streptomyces sp. Strain AA1529, sequence accession ALAP00000000 [139]

Streptomyces sulphureus L180, sequence accession AJTQ0000000 [140]

\section{Phylum Spirochaetes}

Borrelia crocidurae, sequence accession CP003426 (chromosome), CP003427 to CP003465 (plasmids) [141]

Treponema sp. Strain JC4, sequence accession JQ783348 [142]

\section{Phylum Bacteroidetes}

Flavobacterium sp. Strain F52, sequence accession AKZQ00000000 [143]

Fusobacterium nucleatum subsp. fusiforme ATCC $51190^{\mathrm{T}}$, sequence accession AKXI00000000 [144]

"Imtechella halotolerans" $\mathrm{K} 1$ T, sequence accession AJJU00000000 [145]

\section{Virus genomes \\ Bacteriophage}

Actinophage PIS136, sequence accession JX006077 [146]

Aeromonas hydrophila Phage CC2, sequence accession JX123262 [147]

Bacteriophage BC-611, sequence accession AB712291 [148]

Bacteriophage SSU5, sequence accession JQ965645 [149]

Blattabacterium sp. strain BGIGA, sequence accession [150]

Caulobacter crescentus Bacteriophage $\varphi \mathrm{CbK}$, sequence accession JX163858 [151]

Celeribacter Bacteriophage P12053L, sequence accession JQ809650 [152]

Croceibacter Bacteriophage P2559S, sequence accession JQ867099 [153]

Cronobacter sakazakii Temperate Bacteriophage phiES15 JQ780327 [154]

Marinomonas Bacteriophage P12026, sequence accession JQ867100 [155]

Pectobacterium carotovorum subsp. carotovorum Bacteriophage PP1, sequence accession JQ837901 [156]

Persicivirga bacteriophages P12024L, sequence accession JQ823123 [157]

Persicivirga bacteriophages P12024S, sequence accession JQ823122 [157] 
phage clP1, sequence accession JN051154

[158]

Pseudomonas aeruginosa Siphophage

MP1412, sequence accession JX131330 [159]

Pseudomonas aeruginosa Temperate Phage MP29, sequence accession EU272036 [160]

Pseudomonas aeruginosa Temperate Phage MP42, sequence accession JQ762257 [160]

Pseudomonas Phage $\Phi$-S1, sequence accession JX173487 [161]

Siphophage MP1412, sequence accession JX131330 [162]

Staphylococcus aureus Bacteriophage GH15, sequence accession JQ686190 [163]

Vibrio vulnificus Bacteriophage SSP002, sequence accession JQ692107 [164]

\section{Eukaryotic viruses}

African bovine rotaviruses RVA/Cowwt/ZAF/1603/2007/G6P, sequence accession S9(VP7) JN831209, S4(VP4) JN831210, S6(VP6) JN831211, S1(VP1) JN831212, S2(VP2) JN831213, S3(VP3) JN831214, S5(NSP1) JN831204, S8(NSP2) JN831205, S7(NSP3) JN831206, S10(NSP4) JN831207, S11(NSP5) JN831208 [165]

African bovine rotaviruses RVA/Cowwt/ZAF/1604/2007/G8P, sequence accession S9(VP7) JN831220, S4(VP4) JN831221, S6(VP6) JN831222, S1(VP1) JN831223, S2(VP2) JN831224, S3(VP3) JN831225, S5(NSP1) JN831215, S8(NSP2) JN831216, S7(NSP3) JN831217, S10(NSP4) JN831218, S11(NSP5) JN831219 [165]

African bovine rotaviruses RVA/Cowwt/ZAF/1605/2007/G6P, sequence accession S9(VP7) JN831231, S4(VP4) JN831232, S6(VP6) JN831233, S1(VP1) JN831234, S2(VP2) JN831235, S3(VP3) JN831236, S5(NSP1) JN831226, S8(NSP2) JN831227, S7(NSP3) JN831228, S10(NSP4) JN831229, S11(NSP5) JN831230 [165]

Avian Leukosis Virus, sequence accession JX254901 [166]

Avian Influenza Virus H3N2, sequence accession JX175250 through JX175257 [167]

Avian Influenza Virus H5N2, sequence accession JQ990145 through JQ990152 [168]
Avian-Like H4N8 Swine Influenza, sequence accession JX151007 through JX151014 [169]

Avian Paramyxovirus, sequence accession JQ886184 [170]

Avian Tembusu-Related Virus Strain WR, sequence accession JX196334 [171]

Bluetongue Virus Serotype 9, sequence accession JX003687 to JX003696 [172]

Bluetongue Virus Serotype 16, sequence accession [173]

Bombyx mori Nucleopolyhedrovirus, sequence accession JQ991009 [174]

Bovine Viral Diarrhea Virus 2, sequence accession JF714967 [175]

Bovine Foamy Viruses, sequence accession JX307861 [176]

Canine Noroviruses, sequence accession FJ692500 and FJ692501 [177]

Chicken Anemia Virus, sequence accession JX260426 [178]

Chikungunya Virus, sequence accession JX088705 [179]

Chinese Virulent Avian Coronavirus GX-YL5, sequence accession HQ848267 [180]

Chinese Virulent Avian Coronavirus GX-YL9, sequence accession HQ850618 [180]

Coxsackievirus B4, sequence accession JX308222 [181]

Enterovirus C (HEV-C117), sequence accession JX262382 [182]

Genotype 4 Hepatitis E Virus Strain, sequence accession JQ993308 [183]

H10N8 Avian Influenza Virus, sequence accession JQ924786 to JQ924793 [184]

H9N2 Subtype Influenza Virus FJG9, sequence accession JF715008.1, JN869514.1 through JN869520.1 [185].

Herpes Simplex Virus 1 Strain McKrae, sequence accession JX142173 [186]

Human Coronavirus NL63, sequence accession JX104161 [187]

Human G10P Rotavirus, sequence accession AB714258 through AB714268 [188]

Ikoma Lyssavirus, sequence accession JX193798 [189]

Korean sacbrood viruses AmSBV-Kor19, sequence accession JQ390592 [190] 
Korean sacbrood viruses AmSBV-Kor21, sequence accession JQ390591 [190]

Mitochondrion of Frankliniella occidentalis, sequence accession JN835456 [191]

New Circular DNA Virus from Grapevine, sequence accession JQ901105 [192]

Novel Porcine Epidemic Diarrhea Virus, sequence accession JX112709 [193]

Pararetrovirus, sequence accession JQ926983 [194]

Parechovirus, sequence accession JX050181 [195]

Peste des Petits Ruminants Virus, sequence accession JX217850 [196]

Polyomavirus, sequence accession JQ412134 [197]

Porcine Circovirus 2b Strain CC1, sequence accession JQ955679 [198]

Porcine circovirus type 2 (PCV2), sequence accession JX294717 [199]

Porcine Epidemic Diarrhea Virus Strain AJ1102, sequence accession JX188454 [200]

Porcine Sapelovirus Strain YC2011, sequence accession JX286666 [201]

Respiratory Syndrome Virus Strain QY2010, sequence accession JQ743666 [202]

SAT 2 Foot-and-Mouth Disease Virus, sequence accession JX014255 [203]

SAT 2 Foot-and-Mouth Disease Virus PAT, sequence accession JX014256 [203]

Street Rabies Virus, sequence accession HQ450386 [204]

\section{References}

1. Mardanov AV, Kochetkova TV, Beletsky AV, Bonch-Osmolovskaya EA, Ravin NV, Skryabin KG. Complete Genome Sequence of the Hyperthermophilic Cellulolytic Crenarchaeon "Thermogladius cellulolyticus" 1633. I Bacteriol 2012; 194:4446-4447.

http://dx.doi.org/10.1128//B.00894-12 PubMed

2. Gorlas A, Robert C, Gimenez G, Drancourt M, Raoult D. Complete Genome Sequence of Methanomassiliicoccus luminyensis, the Largest Genome of a Human-Associated Archaea Species. J Bacteriol 2012; 194:4745.

http://dx.doi.org/10.1128//B.00956-12 PubMed

3. Jung JH, Lee JH, Holden JF, Seo DH, Shin H, Kim HY, Kim W, Ryu S, Park CS. Complete Genome
Waterfowl aviadenovirus goose adenovirus 4, sequence accession JF510462 [205]

\section{Plant genomes}

\section{Plants}

cpDNA of Smilax china, sequence accession NC_015104 [206]

Elodea canadensis, sequence accession JQ310743 [207]

Ogura-type mitochondrial genome, sequence accession AB694743 [208]

\section{Fungus}

Aspergillus oryzae Strain 3.042, sequence accession AKHY00000000 [209]

Rhodosporidium toruloides MTCC 457, sequence accession AJMJ00000000 [210]

\section{Animal genomes}

Helicoverpa armigera, sequence accession HQ613271 [211]

\section{Plasmids}

plasmidIncN plasmid pRSB201, sequence accession JN102341 [212]

plasmidIncN plasmid pRSB203, sequence accession JN102342 [212]

plasmidIncN plasmid pRSB205, sequence accession JN102343 [212]

plasmidIncN plasmid pRSB206, sequence accession JN102344 [212]

Sequence of the Hyperthermophilic Archaeon Pyrococcus sp. Strain ST04, Isolated from a DeepSea Hydrothermal Sulfide Chimney on the Juan de Fuca Ridge. J Bacteriol 2012; 194:4434-4435. http://dx.doi.org/10.1128//B.00824-12 PubMed

4. Fujimura R, Sato Y, Nishizawa T, Oshima K, Kim SW, Hattori M, Kamijo T, Ohta H. Complete Genome Sequence of Leptospirillum ferrooxidans Strain C2-3, Isolated from a Fresh Volcanic Ash Deposit on the Island of Miyake, Japan. J Bacteriol 2012; 194:4122-4123. http://dx.doi.org/10.1128//B.00696-12 PubMed

5. Tagwerker $\mathrm{C}$, Dupont $\mathrm{CL}$, Karas BJ, Ma L, Chuang RY, Benders GA, Ramon A, Novotny M, Monta- 
gue MG, Venepally $P$, et al. Sequence analysis of a complete $1.66 \mathrm{Mb}$ Prochlorococcus marinus MED4 genome cloned in yeast. Nucleic Acids Res 2012. http://dx.doi.org/10.1093/nar/gks823 PubMed

6. Malhotra J, Dua A, Saxena A, Sangwan N, Mukherjee U, Pandey N, Rajagopal R, Khurana P, Khurana JP, Lal R. Genome Sequence of Acinetobacter sp. Strain HA, Isolated from the Gut of the Polyphagous Insect Pest Helicoverpa armigera. J Bacteriol 2012; 194:5156. http://dx.doi.org/10.1128//B.01194-12 PubMed

7. Fondi M, Orlandini V, Emiliani G, Papaleo MC, Maida I, Perrin E, Vaneechoutte M, Dijkshoorn L, Fani R. Draft Genome Sequence of the Hydrocarbon-Degrading and Emulsan-Producing Strain Acinetobacter venetianus RAG- $1^{\top}$. I Bacteriol 2012; 194:4771-4772.

http://dx.doi.org/10.1128//B.01019-12 PubMed

8. Hao X, Xie P, Johnstone L, Miller SJ, Rensing C, Wei G. Genome Sequence and Mutational Analysis of Plant-Growth-Promoting Bacterium Agrobacterium tumefaciens CCNWGS0286 Isolated from a Zinc-Lead Mine Tailing. Appl Environ Microbiol 2012; 78:5384-5394. http://dx.doi.org/10.1128/AEM.01200-12 PubMed

9. Phung LT, Trimble WL, Meyer F, Gilbert JA, Silver S. Draft Genome Sequence of Alcaligenes faecalis subsp. faecalis NCIB 8687 (CCUG 2071). J Bacteriol 2012; 194:5153. http://dx.doi.org/10.1128//B.01185-12 PubMed

10. Kim J. Jung J, Sung J-S, Chun J, Park W. Genome Sequence of Pectin-Degrading Alishewanella agri, Isolated from Landfill Soil. J Bacteriol 2012; 194:5135-5136. http://dx.doi.org/10.1128//B.01129-12 PubMed

11. Jung J, Choi S, Chun J, Park W. Genome Sequence of Pectin-Degrading Alishewanella aestuarii Strain B11T, Isolated from Tidal Flat Sediment. J Bacteriol 2012; 194:5476. http://dx.doi.org/10.1128/JB.01255-12 PubMed

12. Heggeset TMB, Krog A, Balzer S, Wentzel A, Ellingsen TE, Brautaset T. Genome Sequence of Thermotolerant Bacillus methanolicus: Features and Regulation Related to Methylotrophy and Production of I-Lysine and I-Glutamate from Methanol. Appl Environ Microbiol 2012; 78:5170-5181. http://dx.doi.org/10.1128/AEM.00703-12 PubMed

13. Park SJ, Ghai R, Martín-Cuadrado AB, RodríguezValera F, Jung MY, Kim JG, Rhee SK. Draft Genome Sequence of the Sulfur-Oxidizing Bacte- rium "Candidatus Sulfurovum sediminum" AR, which Belongs to the Epsilonproteobacteria. J Bacteriol 2012; 194:4128-4129. http://dx.doi.org/10.1128//B.00741-12 PubMed

14. Rolain JM, Vayssier-Taussat M, Gimenez G, Robert C, Fournier PE, Raoult D. Genome Sequence of Bartonella birtlesii, a Bacterium Isolated from Small Rodents of the Genus Apodemus. I

Bacteriol 2012; 194:4779. http://dx.doi.org/10.1128//B.01044-12 PubMed

15. Kim H, Jeong $\mathrm{W}$, Jeoung HY, Song JY, Kim JS, Beak JH, Parisutham V, Lee SK, Kim JW, Kim JY, et al. Complete Genome Sequence of Brucella abortus A13334, a New Strain Isolated from the Fetal Gastric Fluid of Dairy Cattle. J Bacteriol 2012; 194:5444. http://dx.doi.org/10.1128//B.01124-12 PubMed

16. Kim JS, Jeong $W$, Jeoung HY, Song JY, Kim H, Beak JH, Parisutham V, Lee SK, Kim JW, Kim JY, et al. Complete Genome Sequence of Brucella canis Strain HSK A52141, Isolated from the Blood of an Infected Dog. J Bacteriol 2012; 194:5134. http://dx.doi.org/10.1128//B.01125-12 PubMed

17. Ke Y, Yuan X, Zhen Q, Wang Y, Li T, Sun Y, Song $\mathrm{H}$, Huang L, Wang D, Cui B, et al. Genome Sequence of Brucella melitensis S66, an Isolate of Sequence Type 8, Prevalent in China. J Bacteriol 2012; 194:5451. http://dx.doi.org/10.1128//B.01202-12 PubMed

18. Ke $Y$, Yuan $X$, Wang $Y$, Bai $Y, X u J$, Song $H$, Huang L, Chen Z. Genome Sequences of Brucella melitensis $16 \mathrm{M}$ and Its Two Derivatives 16M1 w and 16M13w, Which Evolved In Vivo. J Bacteriol 2012; 194:5489. http://dx.doi.org/10.1128//B.01293-12 PubMed

19. Kwak MJ, Song JY, Kim SY, Jeong H, Kang SG, Kim BK, Kwon SK, Lee CH, Yu DS, Park SH, et al. Complete Genome Sequence of the Endophytic Bacterium Burkholderia sp. Strain KJ006. I Bacteriol 2012; 194:4432-4433. http://dx.doi.org/10.1128//B.00821-12 PubMed

20. Nazir R, Hansen MA, Sørensen S, van Elsas JD. Draft Genome Sequence of the Soil Bacterium Burkholderia terrae Strain BS001, Which Interacts with Fungal Surface Structures. J Bacteriol 2012; 194:4480-4481. http://dx.doi.org/10.1128//B.00725-12 PubMed

21. Zhuo Y, Liu L, Wang Q, Liu X, Ren B, Liu M, Ni $\mathrm{P}$, Cheng YQ, Zhang L. Revised Genome Sequence of Burkholderia thailandensis MSMB43 with Improved Annotation. I Bacteriol 2012; 
OW Nelson and GM Garrity

194:4749-4750.

http://dx.doi.org/10.1128/JB.00931-12 PubMed

22. Shi X, Yu M, Yan S, Dong S, Zhang XH. Genome Sequence of the Thermostable-Agarase-Producing Marine Bacterium Catenovulum agarivorans YM01T, Which Reveals the Presence of a Series of Agarase-Encoding Genes. I Bacteriol 2012; 194:5484. http://dx.doi.org/10.1128/JB.01283-12 PubMed

23. Chan GF, Gan HM, Rashid NAA. Genome Sequence of Citrobacter sp. Strain A1, a DyeDegrading Bacterium. J Bacteriol 2012; 194:54855486. http://dx.doi.org/10.1128//B.01285-12 $\underline{\text { PubMed }}$

24. Shin H, Lee JH, Choi Y, Ryu S. Complete Genome Sequence of the Opportunistic Food-Borne Pathogen Cronobacter sakazakii ES15. J Bacteriol 2012; 194:4438-4439. http://dx.doi.org/10.1128//B.00841-12 PubMed

25. Li B, Shi Y, Ibrahim M, Liu H, Shan C, Wang Y, Kube M, Xie GL, Sun G. Genome Sequence of the Rice Pathogen Dickeya zeae Strain ZJU1202. J Bacteriol 2012; 194:4452-4453. http://dx.doi.org/10.1128/JB.00819-12 PubMed

26. Shankar M, Ponraj P, Ilakiam D, Rajendhran J, Gunasekaran P. Genome Sequence of the Plant Growth-Promoting Bacterium Enterobacter cloacae GS1. J Bacteriol 2012; 194:4479. http://dx.doi.org/10.1128/JB.00964-12 PubMed

27. Chen Z, Chang D, Zou Y, Su L, Zhu Y, Fang X, Wang J, Guo Y, Zhao J, Li D, et al. Genome Sequence of Enterococcus faecium Clinical Isolate LCT-EF128. J Bacteriol 2012; 194:4765. http://dx.doi.org/10.1128/JB.00996-12 PubMed

28. Witzel K, Gwinn-Giglio M, Nadendla S, Shefchek K, Ruppel S. Genome Sequence of Enterobacter radicincitans DSM16656T, a Plant GrowthPromoting Endophyte. / Bacteriol 2012;

194:5469. http://dx.doi.org/10.1128/JB.01193-12 PubMed

29. Yi H, Cho YJ, Yong D, Chun J. Genome Sequence of Escherichia coli J53, a Reference Strain for Genetic Studies. J Bacteriol 2012; 194:3742-3743. http://dx.doi.org/10.1128/JB.00641-12 PubMed

30. Li T, Pu F, Yang R, Fang X, Wang J, Guo Y, Chang D, Su L, Guo N, Jiang X, et al. Draft Genome Sequence of Escherichia coli LCT-EC106. J Bacteriol 2012; 194:4443-4444. http://dx.doi.org/10.1128//B.00853-12 $\underline{\text { PubMed }}$

31. Jeong $H$, Zhao F, Igori D, Oh KH, Kim SY, Kang SG, Kim BK, Kwon SK, Lee CH, Song JY, et al.
Genome Sequence of the Hemolytic-Uremic Syndrome-Causing Strain Escherichia coli NCCP15647. J Bacteriol 2012; 194:3747-3748. http://dx.doi.org/10.1128/JB.00651-12 PubMed

32. Kim M, Yi H, Cho YJ, Jang J, Hur HG, Chun J. Draft Genome Sequence of Escherichia coli W26, an Enteric Strain Isolated from Cow Feces. I

Bacteriol 2012; 194:5149-5150.

http://dx.doi.org/10.1128/JB.01180-12 PubMed

33. Gao L, Zhou J, Liu J, Du G, Chen J. Draft Genome Sequence of Gluconobacter oxydans WSH-003, a Strain That Is Extremely Tolerant of Saccharides and Alditols. J Bacteriol 2012; 194:4455-4456. http://dx.doi.org/10.1128/JB.00837-12 $\underline{\text { PubMed }}$

34. Kim KK, Lee KC, Jeong H, Stevens DA, Lee JS. Draft Genome Sequence of the Human Pathogen Halomonas stevensii S18214T. J Bacteriol 2012; 194:5143. http://dx.doi.org/10.1128/JB.01071-12 PubMed

35. Goto T, Ogura Y, Hirakawa H, Tomida J, Morita Y, Akaike T, Hayashi T, Kawamura Y. Complete Genome Sequence of Helicobacter cinaedi Strain PAGU611, Isolated in a Case of Human Bacteremia. J Bacteriol 2012; 194:3744-3745. http://dx.doi.org/10.1128/JB.00645-12 PubMed

36. Behrens W, Bönig T, Suerbaum S, Josenhans C. Genome Sequence of Helicobacter pylori hpEurope Strain N6. J Bacteriol 2012; 194:37253726. http://dx.doi.org/10.1128/JB.00386-12 PubMed

37. Weiss VA, Faoro H, Tadra-Sfeir MZ, Raittz RT, de Souza EM, Monteiro RA, Cardoso RLA, Wassem R, Chubatsu LS, Huergo LF, et al. Draft Genome Sequence of Herbaspirillum lusitanum P6-12, an Endophyte Isolated from Root Nodules of Phaseolus vulgaris. J Bacteriol 2012; 194:41364137. http://dx.doi.org/10.1128/JB.00657-12 PubMed

38. Lee GW, Lee KJ, Chae JC. Genome Sequence of Herbaspirillum sp. Strain GW103, a Plant Growth-Promoting Bacterium. / Bacteriol 2012; 194:4150. http://dx.doi.org/10.1128//B.00806-12 PubMed

39. Chang HK, Zylstra GJ, Chae JC. Genome Sequence of n-Alkane-Degrading Hydrocarboniphaga effusa Strain AP103T (ATCC BAA-332T). J Bacteriol 2012; 194:5120. http://dx.doi.org/10.1128/JB.01017-12 PubMed

40. Gan HM, Chew TH, Tay YL, Lye SF, Yahya A. Genome Sequence of Hydrogenophaga sp. Strain PBC, a 4-Aminobenzenesulfonate-Degrading Bac- 
terium. / Bacteriol 2012; 194:4759-4760. http://dx.doi.org/10.1128//B.00990-12 PubMed

41. Liao TL, Lin AC, Chen E, Huang TW, Liu YM, Chang YH, Lai JF, Lauderdale TL, Wang JT, Chang SC, et al. Complete Genome Sequence of Klebsiella oxytoca E718, a New Delhi Metallo- $\beta$ Lactamase-1-Producing Nosocomial Strain. J Bacteriol 2012; 194:5454. http://dx.doi.org/10.1128//B.01216-12 PubMed

42. Marx CJ, Bringel F, Chistoserdova L, Moulin L, Haque MFU, Fleischman DE, Gruffaz C, Jourand P, Knief C, Lee MC, et al. Complete Genome Sequences of Six Strains of the Genus Methylobacterium. J Bacteriol 2012; 194:47464748. http://dx.doi.org/10.1128/JB.01009-12 PubMed

43. Gan HM, Chew TH, Hudson AO, Savka MA. Genome Sequence of Methylobacterium sp. Strain GXF4, a Xylem-Associated Bacterium Isolated from Vitis vinifera L. Grapevine. J Bacteriol 2012; 194:5157-5158. http://dx.doi.org/10.1128//B.01201-12 PubMed

44. Villeneuve C, Martineau C, Mauffrey F, Villemur R. Complete Genome Sequences of Methylophaga sp. Strain JAM1 and Methylophaga sp. Strain JAM7. I Bacteriol 2012; 194:4126-4127. http://dx.doi.org/10.1128//B.00726-12 PubMed

45. Normand P, Gury J, Pujic P, Chouaia B, Crotti E, Brusetti L, Daffonchio D, Vacherie B, Barbe V, Médigue $C$, et al. Genome Sequence of Radiation-Resistant Modestobacter marinus Strain BC501, a Representative Actinobacterium That Thrives on Calcareous Stone Surfaces. J Bacteriol 2012; 194:4773-4774. http://dx.doi.org/10.1128/JB.01029-12 PubMed

46. Ngeow YF, Wong YL, Tan JL, Arumugam R, Wong GJ, Ong CS, Ng KP, Choo SW. Genome Sequence of Mycobacterium massiliense M18, Isolated from a Lymph Node Biopsy Specimen. I Bacteriol 2012; 194:4125. http://dx.doi.org/10.1128//B.00712-12 PubMed

47. Schork S, Schlüter A, Blom J, Schneiker-Bekel S, Pühler A, Goesmann A, Frosch M, Schoen C. Genome Sequence of a Neisseria meningitidis Capsule Null Locus Strain from the Clonal Complex of Sequence Type 198. J Bacteriol 2012; 194:5144-5145. http://dx.doi.org/10.1128//B.01099-12 PubMed

48. Gan HM, Chew TH, Hudson AO, Savka MA. Genome Sequence of Novosphingobium sp. Strain $\operatorname{Rr} 2-17$, a Nopaline Crown Gall-Associated Bacterium Isolated from Vitis vinifera L. Grape- vine. / Bacteriol 2012; 194:5137-5138. http://dx.doi.org/10.1128//B.01159-12 PubMed

49. Clifford RJ, Hang J, Riley MC, Onmus-Leone F, Kuschner RA, Lesho EP, Waterman PE. Complete Genome Sequence of Providencia stuartii Clinical Isolate MRSN 2154. J Bacteriol 2012; 194:37363737. http://dx.doi.org/10.1128//B.00615-12 PubMed

50. Alam M, Roy C, Pyne P, Agarwal A, George A, Ghosh W. Whole-Genome Shotgun Sequence of the Sulfur-Oxidizing Chemoautotroph Pseudaminobacter salicylatoxidans KCT001. I Bacteriol 2012; 194:4743-4744. http://dx.doi.org/10.1128//B.00944-12 PubMed

51. Liu H, Liang R, Tao F, Ma C, Liu Y, Liu X, Liu J. Genome Sequence of Pseudomonas aeruginosa Strain SJTD-1, a Bacterium Capable of Degrading Long-Chain Alkanes and Crude Oil. J Bacteriol 2012; 194:4783-4784. http://dx.doi.org/10.1128//B.01061-12 PubMed

52. Gao C, Hu C, Ma C, Su F, Yu H, Jiang T, Dou P, Wang Y, Qin T, Lv M, et al. Genome Sequence of the Lactate-Utilizing Pseudomonas aeruginosa Strain XMG. I Bacteriol 2012; 194:4751-4752. http://dx.doi.org/10.1128//B.00943-12 PubMed

53. Xie G, Cui Z, Tao Z, Qiu H, Liu H, Ibrahim M, Zhu B, Jin G, Sun G, Almoneafy A, et al. Genome Sequence of the Rice Pathogen Pseudomonas fuscovaginae CB98818. J Bacteriol 2012; 194:5479-5480. http://dx.doi.org/10.1128//B.01273-12 PubMed

54. Park HJ, Shin SC, Kim D. Draft Genome Sequence of Arctic Marine Bacterium Pseudoalteromonas issachenkonii PAMC 22718. J Bacteriol 2012; 194:4140. http://dx.doi.org/10.1128/JB.00744-12 PubMed

55. Gao J, Yu X, Xie Z. Draft Genome Sequence of High-Siderophore-Yielding Pseudomonas sp. Strain HYS. J Bacteriol 2012; 194:4121. http://dx.doi.org/10.1128//B.00688-12 PubMed

56. Triscari-Barberi T, Simone D, Calabrese FM, Attimonelli M, Hahn KR, Amoako KK, Turner RJ, Fedi S, Zannoni D. Genome Sequence of the Polychlorinated-Biphenyl Degrader Pseudomonas pseudoalcaligenes KF707. I Bacteriol 2012; 194:4426-4427. http://dx.doi.org/10.1128//B.00722-12 PubMed

57. Li S, Zhao H, Li Y, Niu S, Cai B. Complete Genome Sequence of the Naphthalene-Degrading Pseudomonas putida Strain ND6. I Bacteriol 2012; 194:5154-5155. http://dx.doi.org/10.1128//B.01190-12 PubMed 
OW Nelson and GM Garrity

58. Liang R, Liu H, Tao F, Liu Y, Ma C, Liu X, Liu J. Genome Sequence of Pseudomonas putida Strain SJTE-1, a Bacterium Capable of Degrading Estrogens and Persistent Organic Pollutants. / Bacteriol 2012; 194:4781-4782.

http://dx.doi.org/10.1128/JB.01060-12 PubMed

59. Proença DN, Santo CE, Grass G, Morais PV. Draft Genome Sequence of Pseudomonas sp. Strain M47T1, Carried by Bursaphelenchus xylophilus Isolated from Pinus pinaster. J Bacteriol 2012; 194:4789-4790. http://dx.doi.org/10.1128//B.01116-12 PubMed

60. Li X, Gong J, Hu Y, Cai L, Johnstone L, Grass G, Rensing C, Wang G. Genome Sequence of the Moderately Halotolerant, Arsenite-Oxidizing Bacterium Pseudomonas stutzeri TS44. I Bacteriol 2012; 194:4473-4474. http://dx.doi.org/10.1128/JB.00907-12 PubMed

61. Gan HM, Chew TH, Tay YL, Lye SF, Yahya A. Genome Sequence of Ralstonia sp. Strain PBA, a Bacterium Involved in the Biodegradation of 4Aminobenzenesulfonate. / Bacteriol 2012;

194:5139-5140. http://dx.doi.org/10.1128//B.01165-12 PubMed

62. Kostka JE, Green SJ, Rishishwar L, Prakash O, Katz LS, Mariño-Ramírez L, Jordan IK, Munk C, Ivanova N, Mikhailova N, et al. Genome Sequences for Six Rhodanobacter Strains, Isolated from Soils and the Terrestrial Subsurface, with Variable Denitrification Capabilities. I Bacteriol 2012; 194:4461-4462. http://dx.doi.org/10.1128//B.00871-12 PubMed

63. Sentausa E, Karkouri KE, Robert C, Raoult D, Fournier PE. Genome Sequence of Rickettsia conorii subsp. caspia, the Agent of Astrakhan Fever. J Bacteriol 2012; 194:4763-4764. http://dx.doi.org/10.1128//B.00992-12 PubMed

64. Dong X, Karkouri KE, Robert C, Raoult D, Fournier PE. Genome Sequence of Rickettsia australis, the Agent of Queensland Tick Typhus. J Bacteriol 2012; 194:5129.

http://dx.doi.org/10.1128//B.01117-12 PubMed

65. Rao Q, Wang S, Zhu DT, Wang XW, Liu SS. Draft Genome Sequence of Rickettsia sp. Strain MEAM1, Isolated from the Whitefly Bemisia tabaci. J Bacteriol 2012; 194:4741-4742.

66. Sentausa E, Karkouri KE, Robert C, Raoult D, Fournier PE. Genome Sequence of Rickettsia conorii subsp. israelensis, the Agent of Israeli Spotted Fever. J Bacteriol 2012; 194:5130-5131. http://dx.doi.org/10.1128//B.01118-12 PubMed
67. Garbeva P, van Elsas JD, de Boer W. Draft Genome Sequence of the Antagonistic Rhizosphere Bacterium Serratia plymuthica Strain PRI-2C. I Bacteriol 2012; 194:4119-4120. http://dx.doi.org/10.1128//B.00679-12 PubMed

68. Wang Y, Yuan Y, Zhou L, Su Q, Fang X, Li T, Wang J, Chang D, Su L, Xu G, et al. Draft Genome Sequence of Serratia marcescens Strain LCT-SM213. I Bacteriol 2012; 194:4477-4478. http://dx.doi.org/10.1128//B.00933-12 PubMed

69. Schuldes J, Orbegoso MR, Schmeisser C, Krishnan HB, Daniel R, Streit WR. Complete Genome Sequence of the Broad-Host-Range Strain Sinorhizobium fredii USDA257. I Bacteriol 2012; 194:4483. http://dx.doi.org/10.1128//B.00966-12 PubMed

70. Anand S, Sangwan N, Lata P, Kaur J, Dua A, Singh AK, Verma M, Kaur J, Khurana JP, Khurana $\mathrm{P}$, et al. Genome Sequence of Sphingobium indicum B90A, a HexachlorocyclohexaneDegrading Bacterium. J Bacteriol 2012; 194:44714472. http://dx.doi.org/10.1128/JB.00901-12 PubMed

71. Allen MJ, Tait K, Mühling M, Weynberg K, Bradley C, Trivedi U, Gharbi K, Nissimov J, Mavromatis K, Jensen CN, et al. Genome Sequence of Stenotrophomonas maltophilia PML168, Which Displays Baeyer-Villiger Monooxygenase Activity. I Bacteriol 2012; 194:4753-4754. http://dx.doi.org/10.1128//B.00949-12 PubMed

72. Cao G, Zhao S, Strain E, Luo Y, Timme R, Wang C, Brown E, Meng J, Allard M. Draft Genome Sequences of Eight Salmonella enterica Serotype Newport Strains from Diverse Hosts and Locations. J Bacteriol 2012; 194:5146. http://dx.doi.org/10.1128//B.01171-12 PubMed

73. Baddam R, Thong KL, Avasthi TS, Shaik S, Yap KP, Teh CSJ, Chai LC, Kumar N, Ahmed N. Whole-Genome Sequences and Comparative Genomics of Salmonella enterica Serovar Typhi Isolates from Patients with Fatal and Nonfatal Typhoid Fever in Papua New Guinea. J Bacteriol 2012; 194:5122-5123. http://dx.doi.org/10.1128//B.01051-12 $\underline{\text { PubMed }}$

74. Proença DN, Santo CE, Grass G, Morais PV. Draft Genome Sequence of Serratia sp. Strain M24T3, Isolated from Pinewood Disease Nematode Bursaphelenchus xylophilus. J Bacteriol 2012; 194:3764. http://dx.doi.org/10.1128//B.00670-12 PubMed 
75. Watanabe T, Kojima H, Fukui M. Draft Genome Sequence of a Psychrotolerant Sulfur-Oxidizing Bacterium, Sulfuricella denitrificans skB26, and Proteomic Insights into Cold Adaptation. App/ Environ Microbiol 2012; 78:6545-6549. http://dx.doi.org/10.1128/AEM.01349-12 PubMed

76. Tao F, Wang X, Ma C, Yang C, Tang H, Gai Z, Xu $P$. Genome Sequence of Xanthomonas campestris JX, an Industrially Productive Strain for Xanthan Gum. J Bacteriol 2012; 194:4755-4756. http://dx.doi.org/10.1128/JB.00965-12 PubMed

77. Sun S, Yang X, Yuan Y, Dai X, Yan Y, Cao H, Luo T, Guo R, Wang X, Song Y, et al. Draft Genome Sequence of Yersinia pestis Strain 2501, an Isolate from the Great Gerbil Plague Focus in Xinjiang, China. J Bacteriol 2012; 194:5447-5448. http://dx.doi.org/10.1128/JB.01150-12 PubMed

78. Wu CJ, Wang HC, Chen CS, Shu HY, Kao AW, Chen PL, Ko WC. Genome Sequence of a Novel Human Pathogen, Aeromonas aquariorum. J Bacteriol 2012; 194:4114-4115. http://dx.doi.org/10.1128/JB.00621-12 PubMed

79. Qin N, Zheng B, Yang F, Chen Y, Guo J, Hu X, Li L. Genome Sequence of Aerococcus viridans LL1. J Bacteriol 2012; 194:4143. http://dx.doi.org/10.1128/JB.00786-12 PubMed

80. Chun JH, Hong KJ, Cha SH, Cho MH, Lee KJ, Jeong DH, Yoo CK, Rhie G. Complete Genome Sequence of Bacillus anthracis H9401, an Isolate from a Korean Patient with Anthrax. J Bacteriol 2012; 194:4116-4117. http://dx.doi.org/10.1128/JB.00159-12 PubMed

81. Liu F, Sun W, Su F, Zhou K, Li Z. Draft Genome Sequence of the Sponge-Associated Strain Bacillus atrophaeus C89, a Potential Producer of Marine Drugs. J Bacteriol 2012; 194:4454. http://dx.doi.org/10.1128//B.00835-12 PubMed

82. Takeno A, Okamoto A, Tori K, Oshima K, Hirakawa H, Toh H, Agata N, Yamada K, Ogasawara N, Hayashi T, et al. Complete Genome Sequence of Bacillus cereus NC7401, Which Produces High Levels of the Emetic Toxin Cereulide. J Bacteriol 2012; 194:4767-4768. http://dx.doi.org/10.1128/JB.01015-12 $\underline{\text { PubMed }}$

83. Jeong $\mathrm{H}$, Jeong DE, Kim SH, Song GC, Park SY, Ryu CM, Park SH, Choi SK. Draft Genome Sequence of the Plant Growth-Promoting Bacterium Bacillus siamensis KCTC 13613T. J Bacteriol 2012; 194:4148-4149. http://dx.doi.org/10.1128//B.00805-12 PubMed

84. Kim BK, Chung J, Kim SY, Jeong H, Kang SG, Kwon SK, Lee CH, Song JY, Yu DS, Ryu CM, et al.
Genome Sequence of the Leaf-Colonizing Bacterium Bacillus sp. Strain 5B6, Isolated from a Cherry Tree. J Bacteriol 2012; 194:3758-3759. http://dx.doi.org/10.1128/JB.00682-12 PubMed

85. Wang X, Luo C, Chen Z. Genome Sequence of the Plant Growth-Promoting Rhizobacterium Bacillus sp. Strain 916. J Bacteriol 2012; 194:54675468. http://dx.doi.org/10.1128/JB.01266-12 PubMed

86. Suarez-Suarez LY, Brunet-Galmes I, PiñaVillalonga JM, Christie-Oleza JA, Peña A, Bennasar A, Armengaud J, Nogales B, Bosch R. Draft Genome Sequence of Citreicella aestuarii Strain 357, a Member of the Roseobacter Clade Isolated without Xenobiotic Pressure from a Petroleum-Polluted Beach. J Bacteriol 2012; 194:54645465. http://dx.doi.org/10.1128/JB.01261-12 PubMed

87. Wu YR, Li Y, Yang KL, He J. Draft Genome Sequence of Butanol-Acetone-Producing Clostridium beijerinckii Strain G117. J Bacteriol 2012; 194:5470-5471. http://dx.doi.org/10.1128/JB.01139-12 PubMed

88. Pethick FE, Lainson AF, Yaga R, Flockhart A, Smith DGE, Donachie W, Cerdeira LT, Silva A, Bol E, Lopes TS, et al. Complete Genome Sequence of Corynebacterium pseudotuberculosis Strain 1/06-A, Isolated from a Horse in North America. J Bacteriol 2012; 194:4476. http://dx.doi.org/10.1128/JB.00922-12 $\underline{\text { PubMed }}$

89. Jiang J, Alvarez C, Kukutla P, Yu W, Xu J. Draft Genome Sequences of Enterobacter sp. Isolate Ag1 from the Midgut of the Malaria Mosquito Anopheles gambiae. J Bacteriol 2012; 194:5481. http://dx.doi.org/10.1128/JB.01275-12 PubMed

90. Zischka M, Kuenne C, Blom J, Dabrowski PW, Linke B, Hain T, Nitsche A, Goesmann A, Larsen J, Jensen LB, et al. Complete Genome Sequence of the Porcine Isolate Enterococcus faecalis D32. J Bacteriol 2012; 194:5490-5491. http://dx.doi.org/10.1128/JB.01298-12 PubMed

91. Horiuchi T, Sakka M, Hayashi A, Shimada T, Kimura T, Sakka K. Complete Genome Sequence of Bacteriophage BC-611 Specifically Infecting Enterococcus faecalis Strain NP-10011. J Virol 2012; 86:9538-9539. http://dx.doi.org/10.1128//VI.01424-12 PubMed

92. Gaechter T, Wunderlin C, Schmidheini T, Solioz M. Genome Sequence of Enterococcus hirae (Streptococcus faecalis) ATCC 9790, a Model Organism for the Study of Ion Transport, Bioenergetics, and Copper Homeostasis. J Bacteriol 2012; 
OW Nelson and GM Garrity

194:5126-5127.

http://dx.doi.org/10.1128//B.01075-12 PubMed

93. Zhao Y, Caspers MP, Abee T, Siezen RJ, Kort R. Complete Genome Sequence of Geobacillus thermoglucosidans TNO-09.020, a Thermophilic Sporeformer Associated with a Dairy-Processing Environment. J Bacteriol 2012; 194:4118. http://dx.doi.org/10.1128//B.00318-12 PubMed

94. Flórez $A B$, Reimundo P, Delgado $S$, Fernández E, Alegría Á, Guijarro JA, Mayo B. Genome Sequence of Lactococcus garvieae IPLA 31405, a Bacteriocin-Producing, Tetracycline-Resistant Strain Isolated from a Raw-Milk Cheese. J Bacteriol 2012; 194:5118-5119. http://dx.doi.org/10.1128//B.00975-12 PubMed

95. Lee JH, Valeriano VD, Shin YR, Chae JP, Kim GB, Ham JS, Chun J, Kang DK. Genome Sequence of Lactobacillus mucosae LM1, Isolated from Piglet Feces. I Bacteriol 2012; 194:4766. http://dx.doi.org/10.1128/JB.01011-12 PubMed

96. Di Cagno RD, Angelis MD, Cattonaro F, Gobbetti M. Draft Genome Sequence of Lactobacillus rossiae DSM 15814T. J Bacteriol 2012; 194:54605461. http://dx.doi.org/10.1128//B.01248-12 PubMed

97. Huang E, Yousef AE. Draft Genome Sequence of Paenibacillus polymyxa OSY-DF, Which Coproduces a Lantibiotic, Paenibacillin, and Polymyxin E1. J Bacteriol 2012; 194:4739-4740. http://dx.doi.org/10.1128//B.00846-12 PubMed

98. Midha S, Ranjan M, Sharma V, Kumari A, Singh PK, Korpole S, Patil PB. Genome Sequence of Pediococcus pentosaceus Strain IE-3. I Bacteriol 2012; 194:4468.

http://dx.doi.org/10.1128//B.00897-12 PubMed

99. Brown SD, Podar M, Klingeman DM, Johnson CM, Yang ZK, Utturkar SM, Land ML, Mosher JJ, Hurt RA, Phelps TJ, et al. Draft Genome Sequences for Two Metal-Reducing Pelosinus fermentans Strains Isolated from a $\mathrm{Cr}(\mathrm{VI})$-Contaminated Site and for Type Strain R7. I Bacteriol 2012;

194:5147-5148.

http://dx.doi.org/10.1128/JB.01174-12 PubMed

100. Bowen De León KBD, Young ML, Camilleri LB, Brown SD, Skerker JM, Deutschbauer AM, Arkin AP, Fields MW. Draft Genome Sequence of Pelosinus fermentans JBW45, Isolated during In Situ Stimulation for $\mathrm{Cr}(\mathrm{VI})$ Reduction. J Bacteriol 2012; 194:5456-5457. http://dx.doi.org/10.1128//B.01224-12 PubMed

101. Brown SD, Podar M, Klingeman DM, Johnson CM, Yang ZK, Utturkar SM, Land ML, Mosher JJ,
Hurt RA, Phelps TJ, et al. Draft Genome Sequences for Two Metal-Reducing Pelosinus fermentans Strains Isolated from a $\mathrm{Cr}(\mathrm{VI})$-Contaminated Site and for Type Strain R7. J Bacteriol 2012;

194:5147-5148.

http://dx.doi.org/10.1128//B.01174-12 PubMed

102. Margolles A, Gueimonde M, Sánchez B. Genome Sequence of the Antarctic Psychrophile Bacterium Planococcus antarcticus DSM 14505. I Bacteriol 2012; 194:4465. http://dx.doi.org/10.1128//B.00888-12 PubMed

103. Busquets A, Peña A, Gomila $M$, Bosch R, Nogales B, García-Valdés E, Lalucat J, Bennasar A. Genome Sequence of Pseudomonas stutzeri Strain JM300 (DSM 10701), a Soil Isolate and Model Organism for Natural Transformation. / Bacteriol 2012; 194:5477-5478.

http://dx.doi.org/10.1128//B.01257-12 PubMed

104. Yoo M, Kim D, Choi KY, Chae JC, Zylstra GJ, Kim E. Draft Genome Sequence and Comparative Analysis of the Superb Aromatic-Hydrocarbon Degrader Rhodococcus sp. Strain DK17. I Bacteriol 2012; 194:4440. http://dx.doi.org/10.1128//B.00844-12 PubMed

105. Wang J, Liu Y, Wan D, Fang X, Li T, Guo Y, Chang D, Su L, Wang Y, Zhao J, et al. WholeGenome Sequence of Staphylococcus aureus Strain LCT-SA112. J Bacteriol 2012; 194:4124. http://dx.doi.org/10.1128//B.00710-12 PubMed

106. Qin N, Ding W, Yao J, Su K, Wu L, Li L. Genome Sequence of Staphylococcus capitis QN1, Which Causes Infective Endocarditis. / Bacteriol 2012; 194:4469-4470. http://dx.doi.org/10.1128//B.00827-12 PubMed

107. Irlinger F, Loux V, Bento P, Gibrat JF, Straub C, Bonnarme P, Landaud S, Monnet C. Genome Sequence of Staphylococcus equorum subsp. equorum Mu2, Isolated from a French SmearRipened Cheese. J Bacteriol 2012; 194:51415142. http://dx.doi.org/10.1128//B.01038-12 PubMed

108. Jiang S, Zheng B, Ding W, Lv L, Ji J, Zhang H, Xiao Y, Li L. Whole-Genome Sequence of Staphylococcus hominis, an Opportunistic Pathogen. J Bacteriol 2012; 194:4761-4762. http://dx.doi.org/10.1128//B.00991-12 PubMed

109. Kim BS, Kim CT, Park BH, Kwon S, Cho YJ, Kim N, Kim CJ, Chun J, Kwak J, Maeng JS. Draft Genome Sequence of Staphylococcus saprophyticus subsp. saprophyticus M1-1, Isolated from the Gills of a Korean Rockfish, Sebastes schlegeli Hilgendorf, after High Hydrostatic Pressure Pro- 
cessing. J Bacteriol 2012; 194:4441-4442. http://dx.doi.org/10.1128//B.00848-12 PubMed

110. Biswas S, Biswas I. Complete Genome Sequence of Streptococcus mutans GS-5, a Serotype c Strain. J Bacteriol 2012; 194:4787-4788. http://dx.doi.org/10.1128//B.01106-12 PubMed

111. Miyoshi-Akiyama T, Watanabe S, Kirikae T. Complete Genome Sequence of Streptococcus pyogenes M1 476, Isolated from a Patient with Streptococcal Toxic Shock Syndrome. I Bacteriol 2012; 194:5466.

http://dx.doi.org/10.1128//B.01265-12 PubMed

112. Martín V, Maldonado-Barragán A, Jiménez $E$, Ruas-Madiedo P, Fernández L, Rodríguez JM. Complete Genome Sequence of Streptococcus salivarius PS4, a Strain Isolated from Human Milk. J Bacteriol 2012; 194:4466-4467. http://dx.doi.org/10.1128/JB.00896-12 PubMed

113. Kang X, Ling N, Sun G, Zhou Q, Zhang L, Sheng Q. Complete Genome Sequence of Streptococcus thermophilus Strain MN-ZLW-002. I Bacteriol 2012; 194:4428-4429. http://dx.doi.org/10.1128/]B.00740-12 PubMed

114. Abbasalizadeh S, Jouzani GS, Juibari MM, Azarbaijani R, Yeganeh LP, Raji MA, Mardi M, Salekdeh GH. Draft Genome Sequence of Ureibacillus thermosphaericus Strain Thermo-BF, Isolated from Ramsar Hot Springs in Iran. I

Bacteriol 2012; 194:4431. http://dx.doi.org/10.1128//B.00634-12 PubMed

115. Wise KS, Calcutt MJ, Foecking MF, Madupu R, DeBoy RT, Röske K, Hvinden ML, Martin TR, Durkin AS, Glass JI, et al. Complete Genome Sequences of Mycoplasma leachii Strain PG50T and the Pathogenic Mycoplasma mycoides subsp. mycoides Small Colony Biotype Strain Gladysdale. J Bacteriol 2012; 194:4448-4449. http://dx.doi.org/10.1128//B.00761-12 PubMed

116. dos Santos AP, Guimaraes AMS, do Nascimento NC, SanMiguel PJ, Messick JB. Complete Genome Sequence of Mycoplasma wenyonii Strain Massachusetts. J Bacteriol 2012; 194:5458-5459. http://dx.doi.org/10.1128//B.01240-12 PubMed

117. Roux V, Robert C, Gimenez G, Gharbi R, Raoult D. Draft Genome Sequence of Actinomyces massiliensis Strain 4401292T. J Bacteriol 2012; 194:5121. http://dx.doi.org/10.1128//B.01039-12 PubMed

118. Stahl B, Barrangou R. Complete Genome Sequences of Probiotic Strains Bifidobacterium animalis subsp. lactis B420 and Bi-07. J Bacteriol
2012; 194:4131-4132.

http://dx.doi.org/10.1128//B.00766-12 PubMed

119. Yu DS, Jeong $\mathrm{H}$, Lee DH, Kwon SK, Song JY, Kim BK, Park MS, Ji GE, Oh TK, Kim JF. Complete Genome Sequence of the Probiotic Bacterium Bifidobacterium bifidum Strain BGN4. I Bacteriol 2012; 194:4757-4758. http://dx.doi.org/10.1128//B.00988-12 PubMed

120. Roux V, Robert C, Gimenez G, Raoult D. Draft Genome Sequence of Brevibacterium massiliense Strain 541308T. J Bacteriol 2012; 194:5151-5152. http://dx.doi.org/10.1128//B.01182-12 PubMed

121. Schröder J, Glaub A, Schneider J, Trost E, Tauch A. Draft Genome Sequence of Corynebacterium bovis DSM 20582, Which Causes Clinical Mastitis in Dairy Cows. J Bacteriol 2012; 194:4437. http://dx.doi.org/10.1128//B.00839-12 PubMed

122. Sangal V, Tucker NP, Burkovski A, Hoskisson PA. Draft Genome Sequence of Corynebacterium diphtheriae Biovar Intermedius NCTC 5011. J Bacteriol 2012; 194:4738. http://dx.doi.org/10.1128//B.00939-12 PubMed

123. Pethick FE, Lainson AF, Yaga $R$, Flockhart $A$, Smith DGE, Donachie W, Cerdeira LT, Silva A, Bol E, Lopes TS, et al. Complete Genome Sequence of Corynebacterium pseudotuberculosis Strain 1/06-A, Isolated from a Horse in North America. J Bacteriol 2012; 194:4476. http://dx.doi.org/10.1128//B.00922-12 PubMed

124. Pethick FE, Lainson AF, Yaga R, Flockhart A, Smith DGE, Donachie W, Cerdeira LT, Silva A, Bol E, Lopes TS, et al. Complete Genome Sequences of Corynebacterium pseudotuberculosis Strains 3/99-5 and 42/02-A, Isolated from Sheep in Scotland and Australia, Respectively. I Bacteriol 2012; 194:4736-4737. http://dx.doi.org/10.1128//B.00918-12 PubMed

125. Sharma P, Diene SM, Gimenez G, Robert C, Rolain JM. Genome Sequence of Microbacterium yannicii, a Bacterium Isolated from a Cystic Fibrosis Patient. J Bacteriol 2012; 194:4785. http://dx.doi.org/10.1128//B.01088-12 PubMed

126. Alonso-Vega $P$, Normand $P$, Bacigalupe $R$, Pujic P, Lajus A, Vallenet D, Carro L, Coll P, Trujillo ME. Genome Sequence of Micromonospora lupini Lupac 08, Isolated from Root Nodules of Lupinus angustifolius. I Bacteriol 2012; 194:4135. http://dx.doi.org/10.1128//B.00628-12 PubMed

127. Wong YL, Choo SW, Tan JL, Ong CS, Ng KP, Ngeow YF. Draft Genome Sequence of Mycobacterium bolletii Strain M24, a Rapidly Growing Mycobacterium of Contentious Taxonomic Status. 
OW Nelson and GM Garrity

J Bacteriol 2012; 194:4475.

http://dx.doi.org/10.1128/JB.00916-12 PubMed

128. Kim BJ, Choi BS, Choi IY, Lee JH, Chun J, Hong $\mathrm{SH}$, Kook YH, Kim BJ. Complete Genome Sequence of Mycobacterium intracellulare Clinical Strain MOTT-36Y, Belonging to the INT5 Genotype. J Bacteriol 2012; 194:4141-4142.

http://dx.doi.org/10.1128/JB.00752-12 PubMed

129. Ngeow YF, Wong YL, Tan JL, Arumugam R, Wong GJ, Ong CS, Ng KP, Choo SW. Genome Sequence of Mycobacterium massiliense M18, Isolated from a Lymph Node Biopsy Specimen. I Bacteriol 2012; 194:4125. http://dx.doi.org/10.1128/JB.00712-12 $\underline{\text { PubMed }}$

130. Raiol T, Ribeiro GM, Maranhão AQ, Bocca $A L$, Silva-Pereira I, Junqueira-Kipnis AP, Brigido MM, Kipnis A. Complete Genome Sequence of MyCObacterium massiliense. J Bacteriol 2012;

194:5455. http://dx.doi.org/10.1128/JB.01219-12 PubMed

131. Choo SW, Wong YL, Tan JL, Ong CS, Wong GJ, $\mathrm{Ng}$ KP, Ngeow YF. Annotated Genome Sequence of Mycobacterium massiliense Strain M154, Belonging to the Recently Created Taxon Mycobacterium abscessus subsp. bolletii comb. nov. J

Bacteriol 2012; 194:4778. http://dx.doi.org/10.1128/JB.01043-12 PubMed

132. Madhavilatha GK, Joseph BV, Paul LK, Kumar RA, Hariharan R, Mundayoor S. Whole-Genome SeFquences of Two Clinical Isolates of Mycobacterium tuberculosis from Kerala, South India. J Bacteriol 2012; 194:4430. http://dx.doi.org/10.1128/JB.00453-12 PubMed

133. Gueimonde M, Bottacini F, van Sinderen D, Ventura M, Margolles A, Sánchez B. Genome Sequence of Parascardovia denticolens IPLA 20019, Isolated from Human Breast Milk. J Bacteriol 2012; 194:4776-4777. http://dx.doi.org/10.1128/JB.01035-12 PubMed

134. Strobel T, Al-Dilaimi A, Blom J, Gessner A, Kalinowski J, Luzhetska M, Pühler A, Szczepanowski R, Bechthold A, Rückert C. Complete genome sequence of Saccharothrix espanaensis DSM 44229T and comparison to the other completely sequenced Pseudonocardiaceae. BMC Genomics 2012; 13:465. http://dx.doi.org/10.1186/1471-2164-13-465 PubMed

135. Han X, Li M, Ding Z, Zhao J, Ji K, Wen M, Lu T. Genome Sequence of Streptomyces auratus Strain AGR0001, a Phoslactomycin-Producing
Actinomycete. / Bacteriol 2012; 194:5472-5473. http://dx.doi.org/10.1128/JB.01155-12 PubMed

136. Zhao C, Li P, Deng Z, Ou HY, McGlinchey RP, $\mathrm{O}^{\prime}$ Hagan D. Insights into fluorometabolite biosynthesis in Streptomyces cattleya DSM46488 through genome sequence and knockout mutants. Bioorg Chem 2012; 44:1-7.

http://dx.doi.org/10.1016/j.bioorg.2012.06.002 PubMed

137. Wang L, Wang S, He Q, Yu T, Li Q, Hong B. Draft Genome Sequence of Streptomyces globisporus C-1027, Which Produces an Antitumor Antibiotic Consisting of a Nine-Membered Enediyne with a Chromoprotein. J Bacteriol 2012; 194:4144. http://dx.doi.org/10.1128/JB.00797-12 PubMed

138. Biswas S, Biswas I. Complete Genome Sequence of Streptococcus mutans GS-5, a Serotype c Strain. J Bacteriol 2012; 194:4787-4788. http://dx.doi.org/10.1128/JB.01106-12 PubMed

139. Xiong ZQ, Wang Y. Draft Genome Sequence of the Marine Streptomyces sp. Strain AA1529, Isolated from the Yellow Sea. J Bacteriol 2012; 194:5474-5475. http://dx.doi.org/10.1128/JB.01247-12 PubMed

140. Zhao X, Geng X, Chen C, Chen L, Jiao W, Yang C. Draft Genome Sequence of the Marine Actinomycete Streptomyces sulphureus L180, Isolated from Marine Sediment. J Bacteriol 2012; 194:4482. http://dx.doi.org/10.1128/JB.00900-12 PubMed

141. Elbir H, Gimenez G, Robert C, Bergström S, Cutler S, Raoult D, Drancourt M. Complete Genome Sequence of Borrelia crocidurae. I Bacteriol 2012; 194:3723-3724. http://dx.doi.org/10.1128/JB.00118-12 PubMed

142. Rosewarne CP, Cheung JL, Smith WJM, Evans PN, Tomkins NW, Denman SE, Cuív PÓ, Morrison M. Draft Genome Sequence of Treponema sp. Strain JC4, a Novel Spirochete Isolated from the Bovine Rumen. J Bacteriol 2012; 194:4130. http://dx.doi.org/10.1128//B.00754-12 PubMed

143. Kolton M, Green SJ, Harel YM, Sela N, Elad Y, Cytryn E. Draft Genome Sequence of Flavobacterium sp. Strain F52, Isolated from the Rhizosphere of Bell Pepper (Capsicum annuum L. cv. Maccabi). J Bacteriol 2012; 194:5462-5463. http://dx.doi.org/10.1128/JB.01249-12 PubMed

144. Park SN, Kong SW, Park MS, Lee JW, Cho E, Lim YK, Choi MH, Kim HS, Chang YH, Shin JH, et al. Draft Genome Sequence of Fusobacterium nucleatum subsp. fusiforme ATCC $51190^{\top}$. J 
Bacteriol 2012; 194:5445-5446. http://dx.doi.org/10.1128//B.01138-12 PubMed

145. Kumar S, Vikram S, Subramanian S, Raghava GPS, Pinnaka AK. Genome Sequence of the Halotolerant Bacterium Imtechella halotolerans K1 ${ }^{\mathrm{T}}$. J Bacteriol 2012; 194:3731.

http://dx.doi.org/10.1128/]B.00506-12 PubMed

146. Bajpai R, Soni V, Khandrika L, Jangir PK, Sharma R, Agrawal P. Genome Sequence of a Novel Actinophage PIS136 Isolated from a Strain of Saccharomonospora sp. J Virol 2012; 86:9552. http://dx.doi.org/10.1128//VI.01529-12 PubMed

147. Shen C, Liu Y, Lu C. Complete Genome Sequence of Aeromonas hydrophila Phage CC2. I Virol 2012; 86:10900.

http://dx.doi.org/10.1128//VI.01882-12 PubMed

148. Horiuchi T, Sakka M, Hayashi A, Shimada T, Kimura T, Sakka K. Complete Genome Sequence of Bacteriophage BC-611 Specifically Infecting Enterococcus faecalis Strain NP-10011. J Virol 2012; 86:9538-9539. http://dx.doi.org/10.1128//VI.01424-12 PubMed

149. Kim M, Kim S, Ryu S. Complete Genome Sequence of Bacteriophage SSU5 Specific for Salmonella enterica serovar Typhimurium Rough Strains. J Virol 2012; 86:10894. http://dx.doi.org/10.1128/JVI.01796-12 PubMed

150. Huang CY, Sabree ZL, Moran NA. Genome Sequence of Blattabacterium sp. Strain BGIGA, Endosymbiont of the Blaberus giganteus Cockroach. J Bacteriol 2012; 194:4450-4451. http://dx.doi.org/10.1128//B.00789-12 PubMed

151. Panis G, Lambert C, Viollier PH. Complete Genome Sequence of Caulobacter crescentus Bacteriophage $\varphi$ CbK. J Virol 2012; 86:10234-10235. http://dx.doi.org/10.1128//VI.01579-12 PubMed

152. Kang I, Jang H, Oh HM, Cho JC. Complete Genome Sequence of Celeribacter Bacteriophage P12053L. J Virol 2012; 86:8339-8340. http://dx.doi.org/10.1128//VI.01153-12 PubMed

153. Kang I, Kang D, Cho JC. Complete Genome Sequence of Croceibacter Bacteriophage P2559S. I Virol 2012; 86:8912-8913. http://dx.doi.org/10.1128//VI.01396-12 PubMed

154. Lee JH, Choi Y, Shin H, Lee J, Ryu S. Complete Genome Sequence of Cronobacter sakazakii Temperate Bacteriophage phiES15. J Virol 2012; 86:7713-7714.

http://dx.doi.org/10.1128/JVI.01042-12 PubMed

155. Kang I, Jang H, Oh HM, Cho JC. Complete Genome Sequence of Marinomonas Bacteriophage
P12026. J Virol 2012; 86:8909-8910.

http://dx.doi.org/10.1128/JVI.01328-12 PubMed

156. Lee JH, Shin H, Ji S, Malhotra S, Kumar M, Ryu S, Heu S. Complete Genome Sequence of Phytopathogenic Pectobacterium carotovorum subsp. carotovorum Bacteriophage PP1. J Virol 2012; 86:8899-8900. http://dx.doi.org/10.1128/JVI.01283-12 PubMed

157. Kang I, Jang H, Cho JC. Complete Genome Sequences of Two Persicivirga Bacteriophages, P12024S and P12024L. J Virol 2012; 86:89078908. http://dx.doi.org/10.1128/JVI.01327-12 PubMed

158. Kelly D, O'Sullivan O, Mills S, McAuliffe O, Ross $\mathrm{RP}, \mathrm{Neve} \mathrm{H}$, Coffey A. Genome sequence of the phage cIP1, which infects the beer spoilage bacterium Pediococcus damnosus. Gene 2012;

504:53-63.

http://dx.doi.org/10.1016/j.gene.2012.04.085 PubMed

159. Bae HW, Chung IY, Sim N, Cho YH. Complete Genome Sequence of Pseudomonas aeruginosa Siphophage MP1412. J Virol 2012; 86:9537. http://dx.doi.org/10.1128/JVI.01403-12 PubMed

160. Chung IY, Cho YH. Complete Genome Sequences of Two Pseudomonas aeruginosa Temperate Phages, MP29 and MP42, Which Lack the PhageHost CRISPR Interaction. J Virol 2012; 86:8336. http://dx.doi.org/10.1128/JVI.01127-12 PubMed

161. Sillankorva S, Kropinski AM, Azeredo J. Genome Sequence of the Broad-Host-Range Pseudomonas Phage $\Phi-S 1$. J Virol 2012; 86:10239. http://dx.doi.org/10.1128/JVI.01605-12 PubMed

162. Bae HW, Chung IY, Sim N, Cho YH. Complete Genome Sequence of Pseudomonas aeruginosa Siphophage MP1412. J Virol 2012; 86:9537. http://dx.doi.org/10.1128/JVI.01403-12 PubMed

163. Gu J, Liu X, Lu R, Li Y, Song J, Lei L, Sun C, Feng $\mathrm{X}, \mathrm{Du} \mathrm{C}, \mathrm{Yu} \mathrm{H}$, et al. Complete Genome Sequence of Staphylococcus aureus Bacteriophage GH15. J Virol 2012; 86:8914-8915. http://dx.doi.org/10.1128/JVI.01313-12 PubMed

164. Lee HS, Choi S, Choi SH. Complete Genome Sequence of Vibrio vulnificus Bacteriophage SSP002. I Virol 2012; 86:7711. http://dx.doi.org/10.1128/JVI.00972-12 PubMed

165. Jere KC, Mlera $L, O^{\prime}$ Neill HG, Peenze I, van Dijk AA. Whole genome sequence analyses of three African bovine rotaviruses reveal that they emerged through multiple reassortment events between rotaviruses from different mammalian spe- 
OW Nelson and GM Garrity

cies. Vet Microbiol 2012; 159:245-250.

http://dx.doi.org/10.1016/j.vetmic.2012.03.040 PubMed

166. Ji J, Li H, Zhang H, Xie Q, Chang S, Shang H, Ma J, Bi Y. Complete Genome Sequence of an Avian Leukosis Virus Isolate Associated with Hemangioma and Myeloid Leukosis in Egg-Type and Meat-Type Chickens. J Virol 2012; 86:1090710908. http://dx.doi.org/10.1128/JVI.01894-12 PubMed

167. Tian J, Zhang C, Qi W, Xu C, Huang L, Li H, Liao M. Genome Sequence of a Novel Reassortant H3N2 Avian Influenza Virus in Southern China. J Virol 2012; 86:9553-9554. http://dx.doi.org/10.1128/JVI.01523-12 PubMed

168. Jiao P, Wei L, Yuan R, Gong L, Cao L, Song Y, Luo K, Ren T, Liao M. Complete Genome Sequence of an $\mathrm{H} 5 \mathrm{~N} 2$ Avian Influenza Virus Isolated from a Parrot in Southern China. J Virol 2012; 86:8890-8891. http://dx.doi.org/10.1128/JVI.01189-12 PubMed

169. Su S, Qi W, Chen J, Cao N, Zhu W, Yuan L, Wang H, Zhang G. Complete Genome Sequence of an Avian-Like H4N8 Swine Influenza Virus Discovered in Southern China. J Virol 2012; 86:9542. http://dx.doi.org/10.1128//VI.01475-12 PubMed

170. Briand FX, Henry A, Massin P, Jestin V. Complete Genome Sequence of a Novel Avian Paramyxovirus. J Virol 2012; 86:7710. http://dx.doi.org/10.1128/JVI.00946-12 PubMed

171. Wan C, Huang Y, Fu G, Shi S, Cheng L, Chen H. Complete Genome Sequence of Avian TembusuRelated Virus Strain WR Isolated from White Kaiya Ducks in Fujian, China. J Virol 2012; 86:10912. http://dx.doi.org/10.1128/JVI.01582-12 PubMed

172. Rao PP, Reddy YN, Hegde NR. Complete Genome Sequence of Bluetongue Virus Serotype 9: Implications for Serotyping. J Virol 2012; 86:8333. http://dx.doi.org/10.1128/JVI.01101-12 PubMed

173. Minakshi P, Singh R, Ranjan K, Kumar P, Joshi CG, Reddy YKM, Prasad G. Complete Genome Sequence of Bluetongue Virus Serotype 16 of Goat Origin from India. J Virol 2012; 86:83378338. http://dx.doi.org/10.1128/JVI.01128-12 PubMed

174. Cheng RL, Xu YP, Zhang CX. Genome Sequence of a Bombyx mori Nucleopolyhedrovirus Strain with Cubic Occlusion Bodies. J Virol 2012; 86:10245. http://dx.doi.org/10.1128/JVI.01639-12 PubMed
175. Liu H, Li Y, Gao M, Wen K, Jia Y, Liu X, Zhang W, Ma B, Wang J. Complete Genome Sequence of a Bovine Viral Diarrhea Virus 2 from Commercial Fetal Bovine Serum. J Virol 2012; 86:10233. http://dx.doi.org/10.1128//VI.01581-12 PubMed

176. Hechler T, Materniak M, Kehl T, Kuzmak J, Löchelt M. Complete Genome Sequences of Two Novel European Clade Bovine Foamy Viruses from Germany and Poland. J Virol 2012; 86:10905-10906. http://dx.doi.org/10.1128//VI.01875-12 PubMed

177. Tse H, Lau SKP, Chan WM, Choi GKY, Woo PCY, Yuen KY. Complete Genome Sequences of Novel Canine Noroviruses in Hong Kong. J Virol 2012; 86:9531-9532. http://dx.doi.org/10.1128//VI.01312-12 PubMed

178. Zhang X, Xie Q, Ji J, Chang S, Liu J, Chen F, Ma J, Bee Y. Complete Genome Sequence Analysis of a Recent Chicken Anemia Virus Isolate and Comparison with a Chicken Anemia Virus Isolate from Human Fecal Samples in China. J Virol 2012; 86:10896-10897. http://dx.doi.org/10.1128//VI.01749-12 PubMed

179. Li XF, Jiang T, Deng YQ, Zhao H, Yu XD, Ye Q, Wang HJ, Zhu SY, Zhang FC, Qin ED, et al. Complete Genome Sequence of a Chikungunya Virus Isolated in Guangdong, China. J Virol 2012; 86:8904-8905. http://dx.doi.org/10.1128/JVI.01289-12 PubMed

180. Mo M, Huang B, Wei P, Wei T, Chen Q, Wang X, Li M, Fan W. Complete Genome Sequences of Two Chinese Virulent Avian Coronavirus Infectious Bronchitis Virus Variants. J Virol 2012; 86:10903-10904. http://dx.doi.org/10.1128//VI.01895-12 PubMed

181. Hu YF, Du J, Zhao R, Xue Y, Yang F, Jin Q. Complete Genome Sequence of a Recombinant Coxsackievirus B4 from a Patient with a Fatal Case of Hand, Foot, and Mouth Disease in Guangxi, China. J Virol 2012; 86:10901-10902. http://dx.doi.org/10.1128/JVI.01808-12 PubMed

182. Daleno C, Piralla A, Scala A, Baldanti F, Usonis V, Principi N, Esposito S. Complete Genome Sequence of a Novel Human Enterovirus C (HEVC117) Identified in a Child with CommunityAcquired Pneumonia. J Virol 2012; 86:1088810889. http://dx.doi.org/10.1128/JVI.01721-12 PubMed

183. Wang H, He Y, Shen Q, Wang X, Yang S, Cui L, Ren L, Sun G, Hua X, Shao S, et al. Complete Genome Sequence of the Genotype 4 Hepatitis E Virus Strain Prevalent in Swine in Jiangsu Province, 
China, Reveals a Close Relationship with That from the Human Population in This Area. / Virol 2012; 86:8334-8335.

http://dx.doi.org/10.1128//VI.01060-12 PubMed

184. Jiao P, Cao L, Yuan R, Wei L, Song Y, Shen D, Gong L, Luo K, Ren T, Liao M. Complete Genome Sequence of an H10N8 Avian Influenza Virus Isolated from a Live Bird Market in Southern China. J Virol 2012; 86:7716. http://dx.doi.org/10.1128//VI.00959-12 PubMed

185. Xie Q, Yan Z, Ji J, Zhang H, Liu J, Sun Y, Li G, Chen F, Xue C, Ma J, et al. Complete Genome Sequence of a Novel H9N2 Subtype Influenza Virus FJG9 Strain in China Reveals a Natural Reassortant Event. / Virol 2012; 86:10240-10241. http://dx.doi.org/10.1128//VI.01623-12 PubMed

186. Macdonald SJ, Mostafa HH, Morrison LA, Davido DJ. Genome Sequence of Herpes Simplex Virus 1 Strain McKrae. J Virol 2012; 86:9540-9541. http://dx.doi.org/10.1128//VI.01469-12 PubMed

187. Geng H, Cui L, Xie Z, Lu R, Zhao L, Tan W. Characterization and Complete Genome Sequence of Human Coronavirus NL63 Isolated in China. J Virol 2012; 86:9546-9547. http://dx.doi.org/10.1128//Vl.01457-12 PubMed

188. Jere KC, Mlera L, O’Neill HG, Peenze I, van Dijk AA. Whole genome sequence analyses of three African bovine rotaviruses reveal that they emerged through multiple reassortment events between rotaviruses from different mammalian species. Vet Microbiol 2012; 159:245-250. http://dx.doi.org/10.1016/j.vetmic.2012.03.040 PubMed

189. Marston DA, Ellis RJ, Horton DL, Kuzmin IV, Wise EL, McElhinney LM, Banyard AC, Ngeleja C, Keyyu J, Cleaveland S, et al. Complete Genome Sequence of Ikoma Lyssavirus. J Virol 2012; 86:10242-10243. http://dx.doi.org/10.1128/JVI.01628-12 PubMed

190. Choe SE, Nguyen LTK, Noh JH, Kweon CH, Reddy KE, Koh HB, Chang KY, Kang SW. Analysis of the complete genome sequence of two Korean sacbrood viruses in the Honey bee, Apis mellifera. Virology 2012; 432:155-161. http://dx.doi.org/10.1016/j.virol.2012.06.008 PubMed

191. Yan D, Tang Y, Xue X, Wang M, Liu F, Fan J. The complete mitochondrial genome sequence of the western flower thrips Frankliniella occidentalis (Thysanoptera: Thripidae) contains triplicate putative control regions. Gene 2012; 506:117-124. http://dx.doi.org/10.1016/j.gene.2012.06.022

PubMed

192. Gan HM, Chew TH, Hudson AO, Savka MA. Genome Sequence of Methylobacterium sp. Strain GXF4, a Xylem-Associated Bacterium Isolated from Vitis vinifera L. Grapevine. I Bacteriol 2012; 194:5157-5158. http://dx.doi.org/10.1128//B.01201-12 PubMed

193. Bi J, Zeng S, Xiao S, Chen H, Fang L. Complete Genome Sequence of Porcine Epidemic Diarrhea Virus Strain AJ1102 Isolated from a Suckling Piglet with Acute Diarrhea in China. J Virol 2012; 86:10910-10911. http://dx.doi.org/10.1128/JVI.01919-12 PubMed

194. Han J, Domier LL, Dorrance A, Qu F. Complete Genome Sequence of a Novel Pararetrovirus Isolated from Soybean. J Virol 2012; 86:9555. http://dx.doi.org/10.1128/JVI.01558-12 PubMed

195. Sun G, Wang Y, Tao G, Shen Q, Cao W, Chang X, Zhang W, Shao C, Yi M, Shao S, et al. Complete Genome Sequence of a Novel Type of Human Parechovirus Strain Reveals Natural Recombination Events. J Virol 2012; 86:8892-8893. http://dx.doi.org/10.1128/JVI.01241-12 PubMed

196. Bao J, Wang Q, Parida S, Liu C, Zhang L, Zhao W, Wang Z. Complete Genome Sequence of a Peste des Petits Ruminants Virus Recovered from Wild Bharal in Tibet, China. J Virol 2012; 86:10885-10886. http://dx.doi.org/10.1128/JVI.01503-12 PubMed

197. Renshaw RW, Wise AG, Maes RK, Dubovi EJ. Complete Genome Sequence of a Polyomavirus Isolated from Horses. J Virol 2012; 86:8903. http://dx.doi.org/10.1128/JVI.01261-12 PubMed

198. Huang Z, Su S, Wei C, Xie J, Zhu W, Chen J, Wang H, Zhang G. Complete Genome Sequence of a Novel Field Strain of Rearranged Porcine Circovirus Type 2 in Southern China. J Virol 2012; 86:10895. http://dx.doi.org/10.1128/JVI.01817-12 PubMed

199. Huang Z, Su S, Wei C, Xie J, Zhu W, Chen J, Wang H, Zhang G. Complete Genome Sequence of a Novel Field Strain of Rearranged Porcine Circovirus Type 2 in Southern China. J Virol 2012; 86:10895. http://dx.doi.org/10.1128/JVl.01817-12 PubMed

200. Bi J, Zeng S, Xiao S, Chen H, Fang L. Complete Genome Sequence of Porcine Epidemic Diarrhea Virus Strain AJ1102 Isolated from a Suckling Piglet with Acute Diarrhea in China. I Virol 2012; 86:10910-10911. http://dx.doi.org/10.1128/JVI.01919-12 PubMed 
201. Chen J, Chen F, Zhou Q, Li W, Song Y, Pan Y, Zhang X, Xue C, Bi Y, Cao Y. Complete Genome Sequence of a Novel Porcine Sapelovirus Strain YC2011 Isolated from Piglets with Diarrhea. J Virol 2012; 86:10898. http://dx.doi.org/10.1128/JVI.01799-12 PubMed

202. Deng Y, Pan Y, Wang D, Zhou Q, Bi Y, Chen F, Song Y. Complete Genome Sequence of Porcine Reproductive and Respiratory Syndrome Virus Strain QY2010 Reveals a Novel Subgroup Emerging in China. J Virol 2012; 86:7719-7720. http://dx.doi.org/10.1128//VI.00977-12 PubMed

203. Valdazo-González B, Knowles NJ, Hammond J, King DP. Genome Sequences of SAT 2 Foot-andMouth Disease Viruses from Egypt and Palestinian Autonomous Territories (Gaza Strip). J Virol 2012; 86:8901-8902. http://dx.doi.org/10.1128//VI.01231-12 PubMed

204. Zhang G, Fu ZF. Complete Genome Sequence of a Street Rabies Virus from Mexico. I Virol 2012; 86:10892-10893. http://dx.doi.org/10.1128/JVI.01778-12 PubMed

205. Kajan GL, Davison AJ, Palya V, Harrach B, Benko $M$. Genome sequence of a waterfowl aviadenovirus, goose adenovirus 4. I Gen Virol 2012. http://dx.doi.org/10.1099/vir.0.042028-0 PubMed

206. Liu J, Qi ZC, Zhao YP, Fu CX. (Jenny) Xiang Q-Y. Complete cpDNA genome sequence of Smilax china and phylogenetic placement of Liliales - Influences of gene partitions and taxon sampling. Mol Phylogenet Evol 2012; 64:545-562. http://dx.doi.org/10.1016/j.ympev.2012.05.010 PubMed

207. Huotari T, Korpelainen H. Complete chloroplast genome sequence of Elodea canadensis and comparative analyses with other monocot plastid genomes. Gene 2012; 508:96-105. http://dx.doi.org/10.1016/i.gene.2012.07.020 PubMed

208. Tanaka Y, Tsuda M, Yasumoto K, Yamagishi H, Terachi T. A complete mitochondrial genome sequence of Ogura-type male-sterile cytoplasm and its comparative analysis with that of normal cytoplasm in radish (Raphanus sativus L.). BMC Genomics 2012; 13:352. http://dx.doi.org/10.1186/1471-2164-13-352 PubMed

209. Zhao G, Yao Y, Qi W, Wang C, Hou L, Zeng B, Cao X. Draft Genome Sequence of Aspergillus oryzae Strain 3.042. Eukaryot Cell 2012; 11:1178. http://dx.doi.org/10.1128/EC.00160-12 PubMed

210. Kumar S, Kushwaha H, Bachhawat AK, Raghava GPS, Ganesan K. Genome Sequence of the Oleaginous Red Yeast Rhodosporidium toruloides MTCC 457. Eukaryot Cell 2012; 11:1083-1084. http://dx.doi.org/10.1128/EC.00156-12 PubMed

211. Xu P, Cheng P, Liu Z, Li Y, Murphy RW, Wu K. Complete Genome Sequence of a Monosense Densovirus Infecting the Cotton Bollworm, Helicoverpa armigera. J Virol 2012; 86:10909. http://dx.doi.org/10.1128/JVI.01912-12 PubMed

212. Eikmeyer F, Hadiati A, Szczepanowski R, Wibberg D, Schneiker-Bekel S, Rogers LM, Brown CJ, Top EM, Pühler A, Schlüter A. The complete genome sequences of four new IncN plasmids from wastewater treatment plant effluent provide new insights into IncN plasmid diversity and evolution. Plasmid 2012; 68:13-24. http://dx.doi.org/10.1016/j.plasmid.2012.01.011 PubMed 